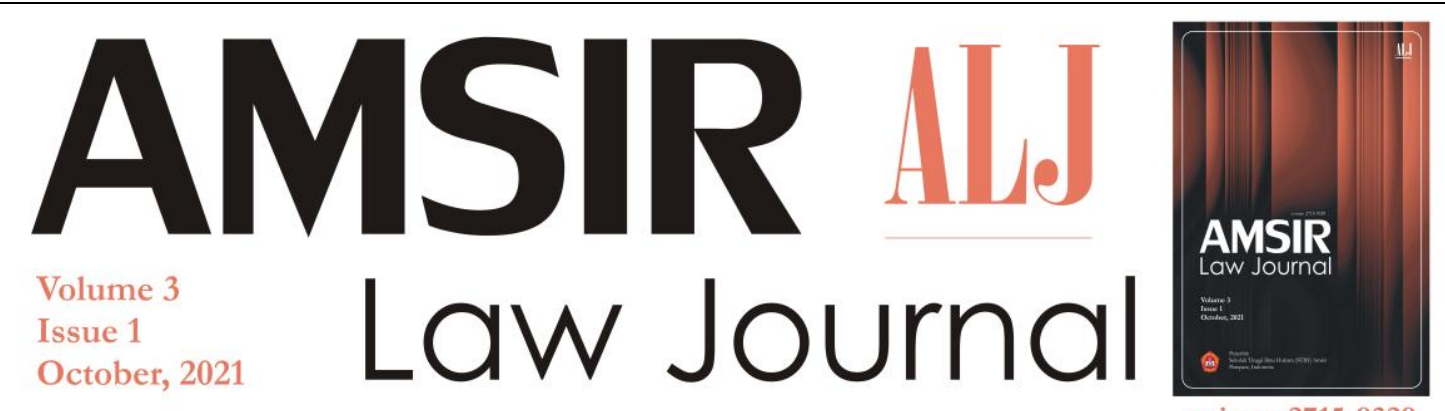

This work is licensed under a Creative Commons Attribution 4.0 International License.

\title{
Quo Vadis: Sanctions for Children Facing the Law
}

\author{
Herman Balla ${ }^{1}$, Arini Asriyani ${ }^{2}$.
}

\section{ARTICLE INFO}

\section{Keywords:}

Sanctions; Children; Law.

How to cite:

Balla, Herman., and Asriyani, Arini. (2021). Quo Vadis:

Sanctions for Children

Facing the Law. Amsir Law

Journal, 3(1), 1-10.

DOI:

10.36746/alj.v3i1.46

\begin{abstract}
The study aims to find out the setting for the sentencing of sanctions against children who commit criminal acts of abuse resulting in death. The type of research used by the author is the empirical normative research type. The results showed that the regulation of sanctions against children who commit crimes that are sentenced to criminal sanctions has been contained in Article 71 paragraph (1) to paragraph (5) of Law No. 11 of 2012 concerning the Criminal Justice System of Children. In addition to the type of sanctions contained in Article 71, sanctions actions can also be imposed on children who commit criminal acts and the overall number of cases obtained from the results of research in the Sungguminas a Court is a total of 7 cases and in its ruling the tendency of judges to give criminal sanctions to prison for children perpetrators of crimes that result in death.
\end{abstract}

Copyright (C) 2021 ALJ. All rights reserved.

\section{Introduction}

The 1945 Constitution on Article 1 paragraph (3) states unequivocally that "the State of Indonesia is the State of Law", not based machstaat. Therefore, the actions taken by the community must be based on regulations. Only the concept of the state of law always wants to regulate every behavior of its people, based on existing regulations to create and maintain and maintain the peace of the nation's life.

The right to life cannot be reduced under any circumstances even including the right of not to be enslaved, not traded, and not tortured, and forced to do something that is not liked or treated inhumanely following his dignity, dignity, and honor as a whole human being. Likewise, humans who must have human rights are protected by law based on Pancasila and the Constitution of the Republic of Indonesia in 1945. So that everyone is entitled and must be treated as a human being who has the same degree as others.

\footnotetext{
${ }^{1}$ Faculty of Law in Andi Sapada Institute of Social and Business Sciences, Parepare, Indonesia. E-mail: hermanballalecture@gmail.com 2 Advocate at AAC Law \& Partner, Makassar, Indonesia.E-mail: ariniasriyani23@gmail.com

3 MAHADIKA, V. P., Nashriana, N., \& Adisti, N. A. (2020). PENJATUHAN SANKSI PIDANA PEMBINAAN DALAM LEMBAGA TERHADAP ANAK PELAKU PENGANLAYAAN MENGAKIBATKAN MATI (STUDI PUTUS AN NO. 1/PID. SUS-ANAK/2020. PN. KPN) (Doctoral dissertation, Sriwijaya University).
} 
Children are an integral part of the survival of a nation and a state. In the Indonesian constitution, children have a strategic role that is expressly stated that the state guarantees the right of every child to survival, growth, and development and protection from violence and discrimination. The development of children into adolescence is very easily influenced by the environment around them. In adolescence, a child is in a sensitive atmosphere or state because his emotional life is often alternated.

Non-miniature children, children have their characteristics and characteristics, so it must be necessary to be different (special), therefore the best protection for the child and his rights and survival in the future must get attention, because in Law No. 35 of 2014 on Child Protection has regulated the special protection that can be provided to children facing the law, more precisely stipulated in Article 59 of Law No. 35 of 2014 on Child Protection.

Facts show that the increasing types of crime always go hand in hand with the development in the world of industrialization and urbanization. This type of crime against the body and the crime against life or commonly known as persecution and murder, are closely related to each other because murder almost always begins with persecution. ${ }^{4}$ For children who violate norms in society and commit criminal acts can be categorized as children who face the law. Children who face the law are children who conflict with the law, children who are victims of criminal acts, and children who are witnesses to criminal acts. Criminal acts committed by children are the same as the types of actions that have been done by adults, the main difference lies only in the perpetrators, namely those committed by children. Age restrictions are usually used as a benchmark for the extent to which children can be held accountable for their criminal acts. Special rules that are used as a basis in examining child criminal acts, namely Law No. 11 of 2012 on the Child Criminal Justice System.

As in Law No. 11 of 2012 regarding sanctions against children determined based on the difference in the age of children, namely for children aged 8 to 14 years only subject to actions, such as returned to their parents, placed in social organizations, or handed over to the state, while children who have reached the age of over 14 years are criminally charged, but it's still an attempt at diversion. The difference in treatment is based on the child's physical, mental, and social growth and development.

The high number of children who behave delinquency needs serious attention so that children who are expected to be potential as the next generation will be protected. Efforts to protect children in trouble with the law have been widely carried out, both at the national and international levels. Globally and internationally the world's attention to children began with the Geneva Declaration on the Rights of the Child of 1924, which was recognized by the international community through a formal statement in the United Nations Universal Declaration of Human Rights in 1989 as well as in the Convention on the Right of the Child on UN Resolution No. 40/25 of November 20, 1989, expressly stating the legal guarantees that must be given by participating states against child offenders. ${ }^{5}$

According to Barda Nawawi Arief, legal protection for children can be interpreted as an effort to protect the law against various freedoms and human rights of children and various interests related to the welfare of children. So, the issue of legal protection for children covers a very wide scope. This is seen from many international documents or

\footnotetext{
4 Nawawi, M. (2017). PENERAPAN SANKSI PIDANA TERHADAP ANAK SEBAGAI PELAKU TINDAK PIDANA PENGANLAYAAN (STUDI KASUS DI PENGADILAN NEGERI DEMAK) (Doctoral dissertation, Fakultas Hukum UNISSULA).

${ }^{5}$ Herwin, S. (2019). Analisis Kesesuaian Sanksi Yang Diberikan Kepada Anak Sebagai Pelaku Dalam Tindak Pidana Kekerasan Berdasarkan Nilai Keadila. ADIL Indonesia Journal, 1(2).
} 
instruments related to children's problems. ${ }^{6}$ Therefore, the Ratification of Convention on the Rights of the Child with Presidential Decree No. 36 of 1990 has opened a new page in the application of international instruments in juvenile justice in Indonesia." "Legal action taken against a child under the age of 18 must take into account the best interests of the child. This is based on the assumption that the child cannot commit a crime or doli incapax and cannot be fully responsible for his actions". ${ }^{8}$ The issue of legal protection for children requires special attention, "special consideration, special services, and special treatment and obtaining special protection for children in legal and judicial matters".

\section{Method}

The type of research used by the author is an empirical normative research type, namely by reviewing various laws and regulations, legal concepts, and judicial rulings. The location of the research selected by the author to collect data to answer the issues discussed, namely in the jurisdiction of the Court of Sungguminasa-Gowa. The location of the research was chosen because the Sungguminasa Court had handled several cases related to the title of the study. Besides, the discussion in this paper will be systematically compiled, in line with the general scientific norms. But in this paper, later the author does not provide an assessment or not in the capacity to assess one object of study, for example, one is superior to the other. The author only concentrates on describing the two streams that are the object of study in this paper. ${ }^{9}$

\section{Regulation of Sanctions Against Children Who Commit Crimes of Persecution That Result in Death}

Criminal law in Indonesia as a means of tackling crime does not seem to be a problem, this is seen from the practice of legislation that has shown that the use of criminal law is part of the policy or political law embraced in Indonesia. The use of criminal law is considered as natural and normal as if its existence were not in question. Though the problem that exists now is the lines of policy or approaches that should be taken in using criminal law.

There are still many children in trouble with the law, who have to undergo criminal justice proceedings. At a very young age, they had to undergo legal proceedings for criminal cases that were so long and tiring, starting from the stage of investigation by the police, prosecution by prosecutors, trials by judges, and the implementation of judge's verdicts. Since the investigation stage, law enforcement has been authorized by law to carry out detention. Not to mention the situation in custody provides a multiplied mental burden for the child, coupled with the psychological pressure that must be faced by them while sitting in the trial as a prisoner.

The mechanism of the criminal justice system aims to prevent future crimes by providing arrest for perpetrators of crimes and prosecution of perpetrators. The presence of Law No. 11 of 2012 can meet the legal balance between the child perpetrators of crime, the community, and the children of victims of crime.

The juvenile criminal justice system law is a substitute for Law No. 3 of 1997, which aims to realize a judiciary that ensures the protection of the best interests of children who face the law. The substance stipulated in the Law No. 11 of 2012, among others, regarding

\footnotetext{
${ }^{6}$ Barda Nawawi Arief, S. H. (2018). Masalab penegakan bukum dan kebijakan bukum pidana dalam penanggulangan kejahatan. Prenada Media. p. 135.

${ }^{7}$ Ibid.

8 Achmad, R. (2005). Upaya Penyelesaian Masalah Anak Yang Berkonflik dengan Hukum. dalam Jurnal Simbur Cahaya. p. 27. 9 Purwanda, S., \& Dewi, M. N. K. (2020). The Effects of Monism and Pluralism on Legal Development of a Nation. Amsir Law Journal, 2(1), 21-26.
} 
the placement of children undergoing judicial proceedings can be placed in the Special Development Institution of Children as well as strict arrangements regarding restorative justice and diversion.

\subsection{Regulation of Sanctions According to Law No. 11 of 2012 on the Criminal Justice System of Children}

The arrangement regarding the type of sanctions given to children under Law No. 11 of 2012 can be measured by the lightness of the child's actions and circumstances and the circumstances at the time of criminal acts which can then be used as the basis for the judge's consideration not to impose criminal or acts on the grounds of justice and humanity. There are several types of sanctions that can be given to the child perpetrators criminal acts that are contained in Article 71 paragraph (1) to paragraph (5) Law No. 11 of 2012:

1) The main criminal for the child;

2) Additional criminals;

3) If in material law is threatened with cumulative imprisonment and fines, criminal fines are replaced with job training.

4) Criminals imposed on children are prohibited from violating the dignity and dignity of the child.

5) Further provisions regarding the form and procedure of criminal conduct as referred to in paragraph (1), paragraph (2), and paragraph (3) are regulated by Government Regulations.

In the case of criminal warnings imposed on children, according to Article 72 of the Law No. 11 of 2012 is a minor crime that does not result in restrictions on the freedom of the child. As for sanctions in the form of criminal charges. In case the judge imposes a criminal with the condition and decides that the child is fostered outside the institution as referred to in Article 71 paragraph (1) letter b number 1, then the institution where education and construction are determined in its decision. As for criminal coaching outside the institution can be a necessity such as:

1) Follow the guidance and counseling program conducted by the development office;

2) Follow therapy in a mental hospital; or

3) Follow therapy due to the abuse of alcohol, narcotics, psychotropic, and other addictive substances.

If during the construction of the child violates the special conditions referred to in Article 73 paragraph (4), the trustee's office may propose to the supervisory judge to extend the construction period that does not exceed the maximum of 2 times the construction period that has not been implemented. Article 76 paragraph (1) describes the criminal service of the community as a criminal that is intended to educate children by increasing their concern for positive community activities. If the child does not fulfill all or part of the obligation in carrying out the criminal service of the community without a valid reason, then the trustee may propose to the supervisory judge to order the Child to repeat all or part of the criminal community service imposed against him and regarding the criminal community service for the Child which can be imposed at least 7 hours and a maximum of 120 hours. Regarding the criminal supervision that can be imposed on the Child as referred to in Article 71 paragraph (1) letter b number 3 at least 3 months and a maximum of 2 years. If the Child is sentenced to criminal supervision as referred to in paragraph (1), the child is placed under the supervision of the public prosecutor and guided by the community supervisor. While criminal job training as referred to in Article 71 paragraph (1) letter c is carried out in 
institutions that carry out job training following the age of the child. Criminal job training as referred to in paragraph (1) is subject to a maximum of 3 months and a maximum of 1 year.

Article 79 of the Law No. 11 of 2012 describes the criminal restriction of freedom; the criminal restriction of freedom is imposed in the case of children committing serious crimes or criminal acts accompanied by violence. Criminal restrictions on freedom imposed on children are at most $1 / 2$ (one second) of the maximum imprisonment threatened against adults. In the case of a special minimum, the prison sentence does not apply to the child, and the provisions regarding imprisonment in the criminal code apply also to children as long as they do not conflict with Law No. 11 of 2012 concerning the Juvenile Criminal Justice System.

Of the various types of sanctions that have been contained in Law No. 11 of 2012, ironically almost all crimes handled by the Indonesian criminal justice system always end up in prison. In prison is not the best solution in solving the problems of crime, especially crimes committed by children. In terms of the application of sanctions against crimes whose perpetrators are a child, then several theories can be used as a basis in the application of criminal sanctions, namely:

1) Reward theory (vergeldingstheorie). According to this theory, the basis of the awarding of punishment should be sought from the crime itself. Where because the evil has given and caused suffering for others in return (vergelding) then the perpetrator must also be given the suffering.

2) Theory of purpose or purpose (doeltheorie). According to this theory, punishment is imposed for carrying out the intent or purpose of the punishment. Where in theory the purpose of this punishment is to prevention crime. Where there is a difference in the invention that is: (a) General prevency (algemene preventive) can be done with the threat of punishment, sentencing, and the implementation of punishment, and (2) The special invention, which is addressed to the person who committed the crime.

3) Combined theory (verenigings theorie). This combined theory is a combination of the theory of reward and the theory of intent and purpose. Where combined, the understanding of this combined theory is to teach that the punishment is to maintain the rule of law in society and to improve the person of the criminal.

The intent of the relative theory (deterrence) views the prosecution not as retaliation for the guilt of the perpetrators of criminal acts, but as a means of achieving a useful goal to protect the community towards welfare. From this theory emerged the purpose of application as a means of prevention. The punishment is imposed for carrying out the purpose or purpose of the punishment, namely to correct public dissatisfaction as a result of the crime. The purpose of punishment should be viewed ideally, other than that the purpose of punishment is to prevent the re-occurrence of crime. This theory aims to prevent and reduce crime. Criminals should be intended to change the conduct of criminals and others who are potentially or likely to commit crimes. Criminal is not merely to retaliate or appeal to a person who has committed a criminal act but has certain useful purposes. The basis of criminal justification lies in its purpose is to reduce the frequency of crimes. The crime is imposed not because people make crimes, but so that people do not commit crimes.

This is certainly different from the absolute theory (retributive theory) which considers that the prosecution is retaliation for the mistakes that have been made, so it is oriented to the deed and lies in the crime itself. The punishment was given because the perpetrator had to accept the sanction for his mistake. 
The Criminal Code used by judges in Indonesia is still very thick adheres to absolute theory (retributive theory). Which sees vengeance as the main purpose and it does not contain means for other purposes, for example for the welfare of society or to improve, educate or re-promote the lawbreaker. While the purpose of the application in Law No. 11 of 2012 on the Children's Criminal Justice System includes the efforts of invention, correction of peace in the community, and the release of the stigma of criminals against children in the community who later shackle children as inmates. This is following the Utilitarian view that the purpose of the prosecution must have beneficial consequences that can be proven. Justice cannot be through the sacrifice of suffering itself, besides that justice can be achieved if the objectives are carried out using the measure of the principles of justice, for example, criminal suffering must not exceed the reward that the Child deserves as a criminal perpetrator. Therefore, the purpose of prosecution is very important as a guideline in giving and dropping criminals, so it can be said that the purpose of the application in law No. 11 of 2012 on the criminal justice system of children is in harmony with what is meant in relative theory (goal theory) and contrary to what is meant in absolute theory (theory of retaliation).

According to the author, the purpose of the prosecution is a shared responsibility for us to think and realize, especially for the implementing and law enforcement officers. The application of children is a process that includes continuous assessment of the goals to be achieved so that matters related to the purpose of the application can be carried out as stipulated in Law Number. 11 of 2012 concerning the Child Criminal Justice System, that children can only be criminally punished based on the type of sanctions in the Law No. 11 of 2012, not the type of criminal sanctions stipulated in Article 10 of the Criminal Code, and the criminal imprisonment of children is a last resort.

However, in cases that cause death as contained in Article 351 paragraph (3) of the Criminal Code, even if committed by a minor, diversion or restorative justice cannot be attempted. This is because to carry out diversion, one must look at the terms and conditions, in which the criminal penalty must be under seven years and is not a repetition of a crime. The judge in addition to considering things that are aggravating and mitigating the child defendant also considers the sense of justice for the victim and the bereaved family. ${ }^{10}$

\subsection{Delik Persecution in the Criminal Code}

The type of criminal sanctions of persecution in the Criminal Code, if associated with the law of the juvenile criminal justice system No. 11 of 2012 as follows:

Delik mishandeling or persecution is stipulated in Article 351 paragraph (1) to paragraph (5) which reads:

1) Persecution is threatened with imprisonment of a maximum of two years and eight months or a maximum fine of four thousand five hundred rupiahs;

2) If the act results in serious injury, the guilty is threatened with a maximum prison term of five years;

3) If it results in death, it is punishable by a maximum prison term of seven years.;

4) With persecution equalized intentionally damaging health;

5) Attempt to commit this crime is not punishable.

In Article 351, speaking only of "persecution" without mentioning one by one the elements of a crime of persecution itself, except to explain only the "intentional harm to the

10 Darmawan, Imam. (2018). Analisis Hukum Penjatuhan Sanksi Bagi Anak Sebagai Pelaku Tindak Pidana Penganiayaan yang Mengakibatkan Kematian. (Doctoral dissertation, Fakultas Hukum UNHAS). p, 118. 
health" of others is the same as persecution. Intentionally inflicting pain or inflicting wounds on the bodies of others is persecution, so it means that a person can be said to mistreat others if the person has opzet or intentional to cause pain, cause injury, or harm to the health of others. R. Soesilo also gave examples of what is meant by "bad feelings", "pain", "wounds", and "damaging health", namely:

1) Bad feelings such as pushing people to plunge into times so wet, telling people to stand in the hot sun, and so on.

2) Pain is for example pinching, pinching, hitting, sticking, and so on.

3) Wounds such as slicing, cutting, stabbing, with knives and others.

4) Damaging health for example people are sleeping and sweating, then opened the window of his room, so that the person caught a cold.

According to R. Soesilo the above actions, must be done intentionally and not with proper intent or over the permissible limit. In the opinion of the author, a person can be categorized as committing "persecution" if it has fulfilled the element of intentionality, as stated in the laws and regulations. Intentionally it can be interpreted that a person has consciously and realized the consequences of the deeds to be done.

However, if the persecution causes death as referred to in Article 351 paragraph (3) then it is threatened with imprisonment of a maximum of seven years and according to $\mathrm{R}$. Soesilo that severe injury or death is only the result that is not intended by the maker if the severe injury is subject to Article 354 of the Criminal Code.

Furthermore, if the abuse is carried out by a child, which according to law No. 35 of 2014 on child protection is "the child is someone who is not yet 18 years old, including a child who is still in the womb", so the threat of imprisonment for children who commit criminal acts is a maximum of $1 / 2$ of the criminal threat to adults as stipulated in Article 81 paragraph (2) of Law No. 11 of 2012.

The application of child abuse often causes debate, because in this case, it has very broad consequences both regarding behavior and stigma in the community and also in the child, but with the issuance of Law No. 11 of 2012 that has been in force since July 30, 2014, the application of prosecution is more nurturing and protecting the child, compared to Law No. 3 of 1997 which is no longer relevant because it is not following the times. Law No. 11 of 2012 adheres to a two-track system where in addition to regulating criminal sanctions also regulates actions (double track system). Through the implementation of this two-track system, the sanctions imposed will better reflect justice, both for perpetrators, victims, and the community so that judges can determine the appropriate and appropriate sanctions against children to be accounted for by children who conflict with the law.

In general, the imposition of criminal sanctions against lawbreakers is often considered as the purpose of the criminal law, therefore if the violator has been brought before the trial and then sentenced to criminal sanctions, then the legal case is considered to have ended. Such views have positioned the circumstances in criminal law and criminal law enforcement as criminal sanctions as stated in the articles violated.

The usual application is applied under the criminal code, not educating children for the better, but aggravating the condition and can increase the child's crime rate. The application of child punishment under Law No. 11 of 2012 is a cornerstone of the enforcement of sanctions against children who commit criminal acts, as mentioned in Article 71 Paragraph (4) of Law No. 11 of 2012 which states "criminals imposed on children are prohibited from violating the dignity and dignity of children". 
With the issuance of Law No. 11 of 2012, it is expected that the welfare and fulfillment of children's rights will be better. Children who commit criminal acts apply special provisions based on Law No. 11 of 2012, as well as the application, is imposed on children no maximum $1 / 2$ of the maximum threat of imprisonment for adults so that the specificity of handling juvenile justice can reduce the provisions in the Criminal Code and The Criminal Code based on the principle of lex specialist derogate generalis. This means that laws of a special nature override laws that are general.

\subsection{Types of Action Sanctions}

In-Law No. 11 of 2012, in addition to criminal sanctions, it is also known to impose sanctions against someone who is proven legitimately and convincingly guilty to provide education and coaching and certain other actions. The types of actions known in Article 82 of Law No. 11 of 2012:

1) Return to parent/guardian;

2) Submission to someone;

3) Treatment in a Mental Hospital;

4) Treatment in Social Welfare Organizations;

5) Obligation to attend formal education and/or training held by the government or private bodies;

6) Revocation of Driver's License;

7) Repairs due to criminal acts. The judge's decision in the form of action can be handed down if: (a) Criminal acts that are proven to be committed by children (12-18 years old) are threatened with imprisonment of less than 7 years; and (b) The maximum period of action concerning treatment at the Social Welfare Organization, the obligation to attend formal education, revocation of driving license is 1 year.

Concerning the implementation of the actions in Article 83 of Law Number 11 of 2012, it only mentions in a limited way the purpose of the act of surrendering the child to someone which is intended for the benefit of the child concerned, and the purpose of the treatment for the child which is intended to assist parents/guardians in educating and providing guidance to the child concerned.

Table. Cases of Child Abuse Causing Death in 2016 to 2019

\begin{tabular}{lcccc}
\multicolumn{1}{c}{ Cases } & $\mathbf{2 0 1 6}$ & $\mathbf{2 0 1 7}$ & $\mathbf{2 0 1 8}$ & $\mathbf{2 0 1 9}$ \\
\hline Number of Cases & 2 & 1 & 1 & 3 \\
\hline Detention Period & 5 and 2 years & 3 years & 4 years & 2.2 years of all \\
\hline Sanction Enforcement & Prison & Prison & Prison & Prison \\
\hline
\end{tabular}

Source: Primary data Court of Sungguminasa-Gowa, 2020 (Edited).

The data in the table above shows that the number of cases of abuse committed by children and which have received court decisions is 6 cases. Namely, among others, first in 2016 there was 1 case with a sanction of 5 years in prison, second in 2017 there was 1 case with a sanction of 3 years in prison, third in 2018 there was 1 case with a witness imposing 4 years in prison and then the fourth in 2019 there are 3 cases with a sanction of 2 years and 2 months in prison.

The data shows that the crime of maltreatment resulting in death by children has increased from year to year and the tendency of judges to impose sanctions, namely by giving 
imprisonment to children. The severity and severity of imprisonment also varies, depending on the extent of the child's role in committing the crime.

The regulation of sanctions in the juvenile criminal justice system Act has been formulated in the form of sanctions in the form of crimes and actions. However, as described earlier and looking at the results of the data found in the field, the imposition of sanctions for children as perpetrators of abuse resulting in death is still based on the philosophy of punishment that is retaliatory.

According to the author, the purpose of punishment to protect the achievement of child welfare, the criteria/standards of the severity of sanctions should not only be seen/measured quantitatively, but rather based on qualitative considerations. Therefore, the actual consideration of the severity of the sanctions (especially the sanctions for coaching within the institution), is not only limited to the reduction of the threat of sanctions for adults, but also the weight of the sanctions that are threatened. As a measure, that the imposition of sanctions is aimed at protecting the interests of children, the threat of deprivation of liberty is avoided as far as possible. As emphasized in various regulations, that the punishment of a child must be appropriate and applied as a last resort for the shortest period.

\section{Conclusion}

In terms of criminal responsibility by children, it cannot be separated from the juvenile criminal justice system which is obliged to prioritize a restorative justice approach, which means that the settlement of criminal cases involves the perpetrator, victim, family of the perpetrator, and victim and other related parties to jointly seek a solution that is satisfactory. Justice by suppressing restoration to its original state and not retaliation. However, in this case, the diversion process cannot be carried out because the criminal threat to the perpetrator's child is above seven years.

\section{References}

Books with an Author:

Barda Nawawi Arief. (2018). Masalah Penegakan Hukum dan Kebijakan Hukum Pidana dalam Penanggulangan Kejahatan. Prenada Media.

Imam Darmawan. (2018). Analisis Hukum Penjatuban Sanksi Bagi Anak Sebagai Pelaku Tindak Pidana Penganiayaan yang Mengakibatkan Kematian. (Doctoral dissertation, Fakultas Hukum UNHAS).

M. Nawawi. (2017). Penerapan Sanksi Pidana terhadap Anak Sebagai Pelaku Tindak Pidana Penganiayaan (Studi Kasus Di Pengadilan Negeri Demak) (Doctoral dissertation, Fakultas Hukum UNISSULA).

V. P. Mahadika, N. Nashriana, \& N. A. Adisti. (2020). Penjatuban Sanksi Pidana Pembinaan dalam Lembaga Terbadap Anak. Pelaku Penganiayaan Mengakibatkan Mati (Studi Putusan NO. 1/PID. SUS-ANAK/2020. PN. KPN) (Doctoral dissertation, Sriwijaya University).

Journal articles:

R. Achmad. (2005). Upaya Penyelesaian Masalah Anak Yang Berkonflik dengan Hukum. dalam Jurnal Simbur Cabaya.

S. Herwin. (2019). Analisis Kesesuaian Sanksi yang Diberikan Kepada Anak Sebagai 
Pelaku dalam Tindak Pidana Kekerasan Berdasarkan Nilai Keadila. ADIL Indonesia Journal, 1(2).

S. Purwanda, \& M. N. K. Dewi. (2020). The Effects of Monism and Pluralism on Legal Development of a Nation. Amsir Law Journal, 2(1), 21-26.

\section{Conflict of Interest Statement:}

The author declares that the research was conducted in the absence of any commercial or financial relationships that could be construed as a potential conflict of interest.

Copyright $(C) 2021$ ALJ. All rightsreserved. 